\title{
Judicial Case Management: The Stay of Pending Claims in Repetitive Cases Provided by the Brazilian Civil Procedure Code of 2015
}

\author{
By Larissa Clare Pochmann Da Silva*
}

This paper analyses the judicial case management from the determination of stay of pending claims on the occasion of the trial of repetitive cases in Brazil. To this end, it begins by highlighting the relevance of judicial case management in enhancing civil justice. It then explains the meaning of repetitive claims before going into the study of the stay of pending claims. After examining the topic, it observes that the stay of pending claims is a mechanism that, in the medium and long term, may be relevant both to the improvement of the jurisdictional performance, avoiding contradictory decisions, and ensuring speed, allowing, after fixing the thesis, the Judiciary can focus on non-repetitive cases.

Keywords: Judicial Case Management; Brazilian Civil Procedure Code of 2015; Stay of Pending Claims; Repetitive Claims

\section{Introduction}

The present paper analysis of the powers of the judge in view of the provision of the Brazilian Civil Procedure Code of 2015 of the stay of pending claims in the trial of repetitive cases, focusing on two questions in the Brazilian`s procedural law scene: i) which are the power of judges in pending claims; ii) how do they work.

For this, through a qualitative approach, the work begins highlighting the relevance of judicial case management in the context of the improvement of civil justice. Then, it is mentioned the concept of judgment of repetitive cases and, finally, the powers of the judge are approached in the perspective of the stay of pending claims.

\section{Judicial Case Management in the Context of the Improvement of Civil Justice}

In 1975, Mauro Cappelletti dealt with a real revolution in the Judiciary, with the gradual abandonment of essentially individualist and liberal paradigms for the adequacy of procedure to social transformations, whose manifestations would be

\footnotetext{
*Post-doctoral Researcher in Procedural Law at Rio de Janeiro State University (UERJ). LLD and Master Degree in Law from Estácio de Sá University (UNESA). Professor of Civil Procedure at Candido Mendes University (UCAM) and Estácio de Sá University (UNESA). Lawyer. Email: larissacpsilva@gmail.com.
} 
both in the improvement of the individual claims and the development of the collective actions ${ }^{1}$.

After more than 40 years of this prediction, the revolution treated by Cappelletti was not able to generate a true metamorphosis of civil justice, but it is undeniable that some transformations have occurred over the years ${ }^{2}$. These transformations are mainly focused on a major dilemma of civil justice ${ }^{3}$, which is the pursuit of balance between efficiency and quality of conflict resolution.

To balance efficiency and quality, the procedural reforms have sought, in essence, not only accelerate, but also improve the procedural rules ${ }^{4}$. For this, in addition to legislative changes, even with a view to summarizing the procedure, some countries began to worry about the availability of official empirical data referring to the judiciary, in order to monitor their results. The follow-up occurs, depending on the region treated, with greater or lesser detail, but can be exemplified, within the European Union, by the studies developed by the European Commission for the Efficiency of Justice (CEPEJ) ${ }^{5}$; in the United States, by the studies developed by Federal Judicial Center ${ }^{6}$ and Uscourts $^{7}$ and in Brazil, through the data available by the National Council of Justice $(\mathrm{CNJ})^{8}$.

In turn, there is also a greater concern with the system of conflict resolution, recognised as imbued with extreme complexity, formalism and costs. The aim is to encourage alternative forms of conflict resolution, so that the judicial process does not show the only way to solve conflicts.

Judicial case management is only one of the strategies that were adopted, both in national courts and in international courts, for the improvement of civil justice. During the history, the rules were developed to provide power to the judges to manage the formalities of judicial proceedings, regulating the progress of disputes, in order to reduce the length and increase the quality of the trial.

It should be emphasised that what is understood as judicial case management does not involve the adoption of a single technique, consisting of different and often combined methods ${ }^{9}$. These techniques can be exemplified as the determination and supervision of the deadlines established for the practice of procedural acts in order to reduce the length of the procedure; the adoption of techniques for summarizing the procedure; techniques to interrogate witnesses; recording of evidence; alternative dispute resolution mechanisms and valuing precedents.

Nowadays, there are several judicial case management records in national and international courts. References to judicial case management are common in the

\footnotetext{
${ }^{1}$ Cappelletti (1975) at 571-572.

${ }^{2}$ Uzelac \& Van Rhee (2018) at 4.

${ }^{3}$ The expression "civil justice" is addressed in this text as the non-criminal sphere and without covering labour justice.

${ }^{4}$ Uzelac \& Van Rhee (2008) at 1.

${ }^{5}$ Dynamic database of European judicial systems.

${ }^{6}$ Database of American judicial systems.

${ }^{7}$ Statistics and Reports.

${ }^{8}$ Statistics and Reports.

${ }^{9}$ Schwarzer (2006) at 1.
} 
English Model ${ }^{10}$ and in the North American Model ${ }^{11}$. Within the framework of the European Union, the adoption of judicial case management has been recommended as one of the best practices for higher courts ${ }^{12}$ and the reference to the theme in Latin America grows ${ }^{13}$.

In Brazil, the judicial case management was not inaugurated with the advent of the Code of Civil procedure of 2015, deserving the following powers of the judge foreseen in the Code of Civil Procedure of 1973: I) stay of pending proceedings; II) powers to decide about their own competence; III) try to reconcile the parties at all times of the procedural march; IV) apply fines; (v) anticipate the effects of the decision; VI) decide on the production of evidence, as well as actively participating in its production ${ }^{14}$. However, it was from March $18^{\text {th }}, 2016$, with the entry into force of the new Civil Procedure Code, that the subject had a clear emphasis. It can be mentioned, as an example, the cooperation provided for in article 6 of the Code of Civil Procedure; the possibility of putting claims together to prevent contradictory decisions; the power of the judge provided for article 139, including to carry out its provisions by means of atypical measures and to change the order of proof; the powers of the judge in winding-up proceedings, as provided for article 375; the decision of redistributing the burden of proof, provided by article $373, \S 1$, in addition to the performance of the judge in the distinction of the cases in which they will render a decision before legal theses fixed in repetitive cases, under the terms of article 489, VI, and 1,037, paragraph 9, as well as the analysis and determination of suspension or not of the processes from the judgment of repetitive cases.

In the present work, the analysis will be delimited to the powers of the judge in view of the stay of pending claims in the trial of repetitive cases.

\section{The Trial of Repetitive Cases in Brazil}

Article 928 of the Civil Procedure Code mentions that repetitive cases are the instruments of the incident of resolution of repetitive demands (IRDR) and repetitive appeals, mechanisms that the decision of material or procedural common questions are binding.

Article 927, section III, of the Civil Procedure Code remembers its binding effect that should be observed by judges and courts in the territorial boundaries in which they were fixed.

According to the lessons of Luiz Guilherme Marinoni, Sérgio Cruz Arenhart and Daniel Mitidiero

Rigorously, the judgment of any and all questions could be repeated, by the mere fact that the questions may be repeated - albeit in different cases. Hence, the incident of

\footnotetext{
${ }^{10}$ Rules 3.1 to 3.21 of Civil Procedure Rules.

${ }^{11}$ Rule 16 of Civil Procedure Rules. See Schwarzer (2006) at 2.

${ }^{12}$ Dusséaux (2017).

${ }^{13}$ Odgers \& Madurera (2019). See also Silva (2010); Ballesteros (2018); and Cabral (2018).

${ }^{14}$ Silva (2010) at 116.
} 
resolving repetitive demands cannot have the same object of repetitive resources: while the incident aims to solve repetitive cases, the special resource aims to form precedents. They are projections of the different functions that each of the cuts, charged with their judgments, takes effect.

That is why we need to resize the scopes of each of the institutes mentioned by art. 928, CPC. The incident of resolving repetitive demands aims to solve cases marked by individual homogeneous rights. Repetitive appeals - such as any extraordinary or special appeals - are aimed at resolving issues for the formation of precedents. ${ }^{15}$

On the incident of resolution of repetitive demands, specifically dealt with in articles 976 to 987 of the Civil Procedure Code, comments Professor Aluisio Gonçalves de Castro Mendes that

The IRDR is returned, mainly, for the rationalisation of judgments, from the solution of common legal issues that are repeated in countless claims and which are thoroughly appreciated by judges, who often arrive at several conclusions. ${ }^{16}$

In turn, the repetitive appeals are provided by articles 1,036 to 1,041 of the Code of Civil procedure. Professor Cassio Scarpinella Bueno comments that:

With the aforementioned multiplicity of extraordinary or special appeals on the basis of the same question of law - the same thesis of constitutional law or federal legal law to focus on concrete cases equal in essence-it is fitting that some appeals are selected and decided by the STF or the STJ, with the remainder of all others, in the expectation that the solution given in cases judged by those courts is applied and observed by all other courts. ${ }^{17}$

Thus, the stay of pending claims will be addressed both in the incident of resolution of repetitive demands and repetitive appeals.

\section{The Application of Judicial Case Management to the Stay of Pending Claims in the Trial of Repetitive Cases}

At this time, the judicial case management in relation to the stay of pending claims will be first analysed in relation to the repetitive appeal procedure and then in the procedure of the incident of resolution of repetitive demands.

\section{The Stay of pending Claims in the proceeding of Repetitive Appeals}

In the context of repetitive appeals, the Civil Procedure Code of 2015 provides in two moments the stay of pending claims: i) one, determined by the court in which the multiplicity of appeals was identified and selected and II)

\footnotetext{
${ }^{15}$ Marinoni, Arenhart \& Mitidiero (2016) at 208.

${ }^{16}$ Mendes (2017) at 10.

${ }^{17}$ Bueno (2019) at 763 .
} 
another at the time of the decision to affect, as determined by the Judge of the Superior Court or the Supreme Court.

In the first, by identifying and selecting appeals for judgment as repetitive in the Superior Court of Justice or the Supreme Court, the president or vice-president of the Court of origin (State Court or Federal Court) will determine the stay of all pending claims, individual or collective, which is in the state or region according to the provisions of article 1,036, $\S 1$ of the Code of Civil Procedure.

The second paragraph of article 1,036 provides that, from that first determination of the stay of the claims, claimants can require the president or the vice-president of the Court to exclude special appeal or the extraordinary appeal that has been interposed after the deadline. Although it does not provide an express deadline for such an application, the claimant will have a period of five (5) days to manifest on that application, it is better to interpret that the deadline for formulating the application will also be five (5) days from the science of the decision of the stay of the claims, according to the provision of article $218, \S 3$ of the Civil Procedure Code, as for the realisation of the equality.

In the second stage, article 1,037, II, of the Civil Procedure Code stipulates that the judge in the Superior or in the Supreme Court shall determine the stay of all pending, individual or collective proceedings, on the same issue on the national territory. The admission of the procedure would thus increase the stay of pending claims for the entire country, not encompassing the completeness of the process involving other issues, including because there is a provision on the code of the partial judgment of the merit ${ }^{18}$.

The stay of pending claims, pursuant to article $1,037, \S 4$, shall endure for a maximum period of up to one (1) year until the appeal is judged. If there is no trial within this period, the provision of article $1,037, \S 5$, which provided for the automatic cessation of the stay of the claims pending, after the expiry of the period of 1 year for the judgment of the representative appeal of the dispute, has been revoked. However, considering the provisions of article 5, section LXXVIII, of the Federal Constitution, on the reasonable duration of the proceeding, it seems appropriate that, if there is no express decision of the judge of the Supreme Court or the Superior Court of Justice extending the period, all the claims in the country will continue ${ }^{19}$.

According to article 982, $\S 2$ of the Civil Procedure Code, the requirement of urgent measures will be to the judge of the pending claim.

Pursuant to article 1,037, $\S 8$ of the Civil Procedure Code, parties must be summoned from the stay of their proceedings, by the judge of the first instance or by the Court, depending on the stage of the proceeding, by virtue of the determination contained in the decision to affect.

\footnotetext{
${ }^{18}$ See Arruda Alvim (2019).

${ }^{19}$ Based on the principle of the reasonable duration of the proceeding, the Superior Court of Justice has already admitted the continuation of a proceeding, with the judgment of the special appeal pending, after the exhaustion of the suspension period marked under Of the Federal Supreme Court. See STJ. EDcl method in Resp N ${ }^{\circ}$ 1269617/MS. Min. Paulo de Tarso Sanseverino. Judgment: September, 26, 2014.
} 
Paragraphs ninth to thirteen of the same law bring an important prediction: the distinguish of the case in relation to what will be decided in the repetitive proceeding. This provision (article $1,037, \S 10$ ) will be to the judge to whom the claim is.

Whereas paragraph 11 provides that the other claimants shall have the period of 5 (five), the deadline for formulating the distinguish shall be five (5) days from the science of the suspension. It will then be decided and that decision (article $1,037, \S 13$ ) is appealed by an interlocutory appeal if the case is at the first instance or internal interlocutory appeal if the decision was rendered by a judge in Court, the rapporteur. If the distinction is recognised (article 1,037, § 12), the judge or rapporteur will continue the proceedings.

However, it should be noted that the stay of pending claims provided by the legislator is not always mandatory. The Superior Court of Justice has determined the stay of pending claims only can be applied if the decision is later than March $18^{\text {th }}, 2016$, date of entry into force of the Civil Procedure Code of 2015. When the affectation was previous, the stay of only appeals was determined, as can be inferred from the themes of repetitive appeals numbers 313, 949, 950 and 951. In issue number 953, Minister Marco Buzzi, in a decision delivered on May $11^{\text {th }}$, 2016, determined just the remaining of special appeals.

Moreover, the Special Court of the Superior Court of Justice, in the judgment of the Resp 1,202,071-SP, of the Rapporteur of the Minister Herman Benjamin, on February $1^{\text {st }}, 2019$, when analyzing the stay of pending appeals recognised that:

The overthrow of the processing of hundreds or thousands of deeds nationwide, for an indefinite time, does not match the Principles of efficiency and access to the judiciary, especially when there is a possibility for the rapporteur to suspend the achievements in which progress can cause legal uncertainty.

This is the recognition that the stay of pending claims will not always be adequate, especially when the issue is about procedural law that usually involves different claims.

The Stay of pending Claims in the Proceeding of Incident of Resolution of Repetitive Demands

Article 982, paragraph I, of the Civil Procedure Code provides that, if the incident is admitted, the judge in Court shall suspend the pending, individual or collective proceedings, which are in the State or in the region. Initially, the stay of pending claims is only in the court that will judge the incident of resolution of repetitive demands.

The determination of stay o pending claims comes from the judge that is the rapporteur of the incident of resolution of repetitive demands, but it is up to the court to communicate to the competent courts (article $982, \S 1$ ), so that each judge will make the stay of the pending claims in their area. 
Although the law only foretell the stay of pending claims, as analysed by Professor Aluisio Gonçalves de Castro Mendes ${ }^{20}$ :

A deeper reflection on the cogent character should be coincidental with the need for concrete analysis, at the end of the adequacy and eventual limits for the stay of pending claims about the resolution of the common question submitted to the incident of resolution of repetitive demands, even if, as a rule, the legislator has foreseen the stay of pending claims, pursuant to article 982, item I, of the Code of Civil Procedure. Reasons may exist, however, for the non-adoption of the concrete situation.

As analysed in repetitive appeals, here, the stay of pending claims could also be partial.

Article 980 expressly stipulates that the period of stay of pending claims shall be 1 (one) year, which shall be counted from the publication of the decision determining the stay of the claims. After this period, the stay of pending claims shall cease, unless the rapporteur decides to postpone the claims pending. The legislator did not foresee a deadline for this extension, but it should not, however, represent an affront to the reasonable length of the proceedings.

In the provisions on the incident of resolution of repetitive demands, there was no express the possibility to distinguish the repetitive case of the case that is being analysed. Thus, they apply to the incident of resolution of repetitive demands the prediction of article 1,037, $\S 9$ to 13 of the Code of Civil procedure, regarding the distinguish. ${ }^{21}$

The stay of pending claims under the court also states that who has standing according to sections II and III of article 977, i.e. parties, public prosecution or public defender, may require the superior court to stay of all pending proceedings, individual or collective, which refer to the subject matter of the incident already established, and are underway in the national territory, in accordance with article $982, \S 3$ to $\S 5$. It does not depend, for this application, on the location of the national territory in which the issue is being discussed.

In order for this measure to be required, the incident must already have been admitted, not only that it has been raised.

The national stay of pending claims was measured by the legislator in favour of legal certainty, in accordance with article $982, \S 3$, but it also seeks the procedural economy, since, from a single incident of resolution of demands it will be possible to standardise the issue at national level.

However, Luiz Guilherme Marinoni, Sergio Cruz Arenhart and Daniel Mitidiero mentions that

Only decision would be indispensable to legal certainty, but this could be achieved in spite of the litigants, who, in the logic of the legislator, regardless of the place of the country in which they are located, may have the exercise of their constitutional rights of action suspended without any appropriate representative being called to act on his behalf. $^{22}$

\footnotetext{
${ }^{20}$ Mendes (2017) at 185 .

${ }^{21}$ Mendes (2017) at 193.

${ }^{22}$ Marinoni, Arenhart \& Mitidiero (2016b) at 97.
} 
It complements article $1,029, \S 4$, which will be for the Superior or the Supreme Court, when deciding to extend the suspension to the national level, if: I) is relevant for legal certainty; II) exceptional social interest and not many stays of the pending claims have been extended to the whole country.

If the suspension is given to the national level, after the incident is judged by the court, who has standing will appeal to the Superior or the Supreme Court to decide the matter for the whole country. If there is no appeal until the deadline, claims will continue.

The Stay of pending Claims from the Perspective of the Improvement of Civil Justice

The stay of pending proceedings due to the judgment of repetitive cases involves the judicial management of proceedings both in relation to the judges of the repetitive trial, as in relation to the judges of each case that is pending.

The judge of the repetitive trial may decide, by affecting the judgment, not to stay the pending proceedings, but also if the determination of stay of the proceedings has occurred and there is no trial within one (1) year, if it would be necessary to extension of the decision, by weighing the relevance that pending proceedings await another time, to avoid contradictory decisions, and the reasonable duration of the proceedings.

In turn, in relation to the judges of each pending case, there is the fulfilment of the determination rendered, through the evaluation of which processes discuss the same question to be decided or which situations are different it means, the distinguish.

After the trial of the repetitive case, all other claims will return to the procedure, with the application of the legal thesis, as preceded by article 985 of the Code of Civil procedure for the incident of resolution of repetitive demands and 1,040 and 1,041 for the repetitive appeals.

If, initially, the stay of pending claims may compromise the reasonable length of the procedure, because the claim would have a longer length while awaiting the decision of the legal thesis, of binding efficacy, according to article 927, III of Civil Procedure Code, after its definition the improvement of the judicial provision is expected.

After the judgment of repetitive claims, all the judges will apply or distinguish the claim and the procedural that was judged by the Court, based on article $489, \S$ 1, paragraph VI of the Civil Procedure Code. This decision don't need to obey the chronological order of judgment (article 12, § 2, item II) and can apply the institutes of the preliminary judgment of dismissal (article 332) and the evidence measure (article 311), so it's possible to the Judiciary to concentrate on the judgment of non-repetitive issues. 


\section{Conclusion}

The judicial case management was one of the measures adopted in several countries to seek the improvement of civil justice, trying to bring the balance between efficiency and celerity. However, it is worth noting that what is called judicial case management is a set of techniques, which can encompass both the procedure and other forms of conflict resolution.

In Brazil, the theme did not emerge with the advent of the Civil Procedure Code of 2015, but from it had a clear emphasis. The work ended up limited to the judicial case management of repetitive cases, more precisely on the stay of pending cases due to the trial of repetitive claims. To do this, before entering the analysis of the stay of pending claims itself, it is possible to delimit that the repetitive case judgments cover both the incident of resolution of repetitive demands and repetitive appeals.

The determination of stay of pending claims, although foreseen by the legislation, is not mandatory, and there are also cases in decisions given in the context of the Superior Court of Justice or the Supreme Court of Justice. The decision to stay claims pending or not be rendered by the judge of the incident resolving repetitive appeals. In a systematic interpretation of the provision of repetitive appeals and in favour of the reasonable length of the claims, that the prediction of the deadline of up to 1 (one) year for the stay of the proceedings due to the pending judgment planned for the incident of resolution of repetitive demands. Thus, after this period, without the judgment being delivered, unless the rapporteur expressly decides, the stay of pending claims would cease.

The enforcement of the decision is made by each judge and the stay of pending claims may also be partial. It is up to each judge to assess whether the case of his/her rapporteurs has a question identical or not to what will be appreciated in the repetitive trial, with the interested parties within five (5) days of the science of the suspension, from distinction provided for in article $1,037, \S 9$ to $\S 13$.

Although there are still issues related to the stay of pending proceedings, the measure may be able, in the medium and long term, to bring the improvement of civil justice, insofar as, despite an initial increase in the length of the claims, from a possible stay decision, after the decision of the repetitive case, with bind effect, each judge will follow or distinguish the specific case in relation to the repetitive judgment.

Moreover, after the judgment of the repetitive mechanisms by a Court, the judgment of repetitive cases will be faster, so that the Judiciary can concentrate on the judgment of non-repetitive issues.

\section{References}

Arruda Alvim, T. (2017). 'CPC abre debate sobre alcance de suspensão de ações em repetitivos', at https://www.conjur.com.br/2017-jun-11/teresa-alvim-cpc-abre-debatesuspensao-acoes-repetitivos 
Ballesteros, P.R. (coordinator) (2018). La gestión judicial de los nuevos tribunales civiles. Santiago, Chile: CEJA-JSCA.

Bueno, C.S. (2019). Manual de Direito Processual Civil. 4. ed. São Paulo: Saraiva.

Brazilian National Council of Justice at https://www.cnj.jus.br/pesquisas-judiciarias/jus ticaemnumeros/2016-10-21-13-13-04/pj-justica-em-numeros

Cabral, A. (2018). 'New trends and perspectives on case management: Proposals on contract procedure and case assignment management' in Peking University Law Journal 6(1):1:5-54, at https://doi.org/10.1080/20517483.2018.1603636

Cappelletti, M. (1975). 'La protection d'intérêts collectifs et de groupe dans le procès civil (Métamorphoses de la procédure civile)' in Revue internationale de droit compare, 27(3): 571-597.

Dusséaux, A. (2017). 'Best practice guide for managing Supreme Courts' at http://at.gov. lv/files/uploads/files/2_Par_Augstako_tiesu/Starptautiska_sadarbiba/BEST\%20PRA CTICE\%20GUIDE.pdf

Dynamic database of European judicial systems, at https://www.coe.int/en/web/cepej/dy namic-database-of-european-judicial-systems

Marinoni, L.G., Arenhart, S.C. \& D. Mitidiero (2016a). Comentários ao Código de Processo Civil. Vol. XV. São Paulo: RT,

Marinoni, L.G., Arenhart, S.C. \& D. Mitidiero (2016b). Comentários ao Código de Processo Civil. Vol. XVI. São Paulo: RT,

Mendes, A.G. (2017). Incidente de resolução de demandas repetitivas. Sistematização, análise e interpretação do novo instituto processual. Rio de Janeiro: Forense.

Odgers, R.G. \& C.F. Madurera (2019). Framing court system for case management: Chilean report, at https://ucsc-chile.academia.edu/RamonGarc\%C3\%ADaOdgers.

Schwarzer, W.W. \& A. Hirsch (2006). The Elements of Case Management: A Pocket Guide for Judges, $2^{\text {nd }}$ ed. Washington, D.C.: Federal Judicial Center.

Silva, P.E.A.da. (2010). Gerenciamento de Processos Judiciais. São Paulo: Saraiva.

Statistics and Reports, at https://www.uscourts.gov/statistics-reports/analysis-report

Uzelac, A. \& Van Rhee, C.H. (Remco) (eds.) (2008). 'Introduction' in Uzelac, A. \& Van Rhee, C.H. (Remco) (eds.) Civil Justice between Efficiency and Quality: From Ius Commune to the CEPEJ. Cambridge: Intersentia, pp. 1-2.

Uzelac, A. \& Van Rhee, C.H. (Remco) (eds.) (2018). 'The Metamorphoses of Civil Justice and Civil Procedure: The Challenges of New Paradigms-Unity and Diversity' in Uzelac, A. \& Van Rhee, C.H. (Remco) (eds.) Transformation of Civil Justice: Unity and Diversity. Cham, Switzerland: Springer, pp. 3-21. 